The Geographical Journal of Nepal

Vol. 11: 137-155, 2018

Central Department of Geography,

Tribhuvan University, Kathmandu, Nepal

\title{
Polycentric settlement as a sustainable development strategy: A case of Baglung district, Nepal
}

\author{
Kabi Prasad Pokhrel ${ }^{1 *}$; Gagan Ale ${ }^{2}$; andAshok Raut ${ }^{3}$ \\ ${ }^{1}$ ResearchCentre for Educational, Innovation and Development, TU,Kathmandu, \\ Nepal; ${ }^{2}$ Central Department of Environmental Science, TU, Kathmandu, Nepal; \\ ${ }^{3}$ Central Department of Geography, TU, Kirtipur, Nepal \\ (*Corresponding Author: drkabipokhrel@gmail.com)
}

This paper is an analysis of potential settlement locations for polycentric centers and their expected role in socio-cultural, economic, environment and transport network as well as spatial development in the Baglung district. Using multi criteria evaluation analysis approach and analytical hierarchy process (AHP) numbers of polycentric settlement centers were identified as the potential centers for socio-economic development at the district level. The empirical findings indicate the polycentric settlement centers not only promote economies and facilitate social integration but also generate a disproportionate number of trips and promote transit ridership. It also helps to strengthen forward and backward linkages between hinterland and service providing center. A balanced and sustainable polycentric development model has been proposed for overall sustainable development through development of polycentric settlement.

Keywords: Polycentric centers; spatial development; territorialdevelopment; social cohesion; Baglung district

\section{Introduction}

Polycentric centers are defined as the growth pole that have relatively high functional activities and it serves to the hinterland areas due to superior geographical locations, production of resources and high level of connectivity or centrality of the area (ESPON, 2014). The use of the term has diversified because according to nature and field of the discipline polycentric centre used as the growth pole and settlement centers by geographers, development pole by development experts and market centers by economists. In a normative perspective, economists, geographers and planners have 
documented the emergence of polycentric centers in post-industrial societies in the developed countries (Nishimura, 2011), as well as in developing countries like China (Chou, 2011).

Traditionally, geographers and spatial development experts used this concept to ensure the balanced and sustainable development of local entities and regions for the utilization of locational advantages (Kaanap, 2012; Anderson \&Bogar, 2001; Brundtland, 1987). Trullén and Boix (2005) consider the concept of polycentrism as the tendency of population and economic activities to concentrate themselves in urban nuclei which have the capacity to exert their influence upon the entire urban structure and upon the areas around them. Haindland Hirschler (2008) found that polycentric development contribute to the balanced economic development and reduce territorial disparities in developing countries. Hallgeir (2004) considers the urban network to be the spine of a territorial system, as polycentrism ensures the transmission of information which is indispensable for the efficient development at the entire territorial system's level. The needs to support polycentric networks as main principle in the regional development is sustained by the results of the detailed analyses of territorial systems, which emphasized interesting evolutions of the development coefficient as a result of the impulses from the central level.

Polycentrism is a concept based on the idea of promoting several decision centers. In territorial planning, the concept assumes a complex approach to social innovation and territorial development, using defined devices, classified depending on their capacity to spread a new quality in the subordinated territorial subsystems (Lynch, 1981). Growth or development poles are grouped in polycentric centers classified according to their capacity to specialize the subordinate space. Polycentric settlement is a development strategy of space based on promoting and implementing some policies of consolidating the development poles or growth poles network (Nishimura, et.al. 2011a). By decisional impulses, the relationships between the polycentric network components are need to be redefined, the strong points are to be improved in a superior manner, and a part of the envisaged territory's problems could be solved (Hall.2009). The analysis of the polarization capacity and field researches identified the main specialization directions represented on the graphic models by means of development vectors which represent as well the directions and a certain type of qualitative load of development, from the settlement centers of superior rank towards the subordinate ones. In identifying the role of each parameters of the polycentric center development, an important role can be played by the concepts of territorial competence and cohesion which is represented by those functionalities which give particularity to the territorial system, and impose it in the competition with the others. Functional specialization is a determinant factor || $138 \|$ 
of territorial competence or polycentric center development. Further, the territorial competence could be envisaged the projections of those competences, which would allow the rural settlement to be remarked in the local settlements' network. The territorial cohesion represents the capacity of a polycentric network's components to stay together by means of developing and multiplying the relationships between them. The polycentric center development approach is based on several decision levels: the national resource capacity, regional development strategy, intraregional development (growth) poles, and local development framework (NFGM-VATI, 2010). Urban settlements development policy accomplishes the functional connection with the capital, having the role of coordinating the distribution of information from the capital to the level of the entire region. Whereas regional development policies are urban settlements with an inferior polarization capacity compared to national development, consolidated by the administrative functions held in time. This category is represented by the present local units which, due to their administrative function, are categorically imposed in the county urban systems. Intraregional development (growth) poles are represented by urban settlements which benefited from the regional context of advantages, which contributed to the increasement of their polarization capacity compared to countryside (Niekerk, 2016). Local development frame has an important role in the functioning of country networks, which contribute to the spread of development from the level of intraregional and regional poles to the local level. The importance of these poles comes from their function of redistributing information in the subordinated rural space. Growth centers are represented by rural settlements, which by the economic activities they hold, transform into development engines for the highly disadvantaged rural spaces (Bevan, et al., 2013). These are indispensable in elaborating the strategies of polycentric development, specific for the highly disadvantaged areas. In this category there are enclosed the settlements which play a central role in the highly rural areas, which by specific strategies contribute to the information transfer towards the periphery of the polycentric settlement centers (Fujita et al., 1999; ESDP, 1999).

Peptenatu et al., (2012) mentioned that there is an issue to create competitive economic areas, evenly distributed on the large territory, with no differences and functional flows between the centre and periphery, a system of human settlements classified by their development potential and interconnected functional networks. The development of human settlements formed by development poles is one of the major challenges of the decision factors and an interdisciplinary research. The isolated geographical spaces lacking the territorial synapses which could connect them to a polarizing centre. Emphasizing on building a regional polycentric network, it can be suggested policy measures to the decrease of territorial disparities determined by the economic crisis, the distribution of central place settlements network and the steps for reaching to a 
re-thinking of administrative structures, which proved incapable of an efficient transfer of information from central to local level. The polycentric development model taken as a new administrative level to encouraging local economies with competitiveness and creating social cohesion, developing enterprise, and to encouraging the development of polycentric networks.

DUDBC (2010) stated that the economic, spatial and mobility trends in Nepal point towards the inevitability of developed dense and compact human settlement in the countryside with a view to materialize the social innovation and cultural practices in the sphere of arts and creativity. To solve the local development problems in the context of rural areas, satisfaction of human needs, diffusion of skills and technology by activating local politics and policy making for valorization of territorial specity through democratic governance or democratization of local development is utmost in order to promote the practice of self-determination economy as people transform their livelihoods and lives by enlarging the power and competence base of localities (Brandi, 2015).Generally, polycentric centers growth process need to be considered as the engine of economic growth, social change, science and technological development in Nepalese context ((NUDS, 2017; NPC, 2015).

In Nepal, majority of the rural population are living in scattered settlements in all three ecological regions where country does not reach minimum population thresholds to be effectively and efficiently provided with basic infrastructure, and social and economic services including job opportunities. There is a policy lacking to discourage monocentric urbanizing trend without urban growth and to increase the service efficiency of the center to the neighbors. Backward linkage of the center by providing efficient services to the periphery and forward linkage of the periphery by increasing the production level both have not developed by the national urban development strategy. So, the dispersed rural settlement patterns, the per capita costs for construction, operation and maintenance of basic infrastructure and other essential services are very high coupled with low economic returns. (DUDBC, 2010; ADB, \& ICTMOD, 2006; NPC, 2013). In the absence of basic life-sustaining services and economic opportunities in the rural areas, the population belonging to economically active age groups has been migrating temporarily or permanently to the urban centers of the country as well as outside the country in search for better services and facilities, and for employment. This trend has become a critical factor affecting rural development in Nepal. This calls for a new thinking or new paradigm shift in rural development approach and processes for providing better services and sustainable livelihood opportunities to the rural population. The national paper on compact settlement development (DUDBC/ CDG-TU, 2003) and designation of hierarchy of humans settlements standards (DUDBC/ CDG-TU, 2004) 
noted that developing integrated compact settlements (ICS) or polycentric settlement for provision of basic services and livelihood opportunities along with the appropriate measures for protection of natural resources and environment could be a viable option and approach to initiate this new thinking, and could help raise the living standards of a majority of population at the district level.

The traditional mode of living sustained by the conventional economic activities in the remote rural and scattered settlements is no longer adequate to meet the rising needs and aspirations of the present day population, let alone that of the future generation. It becomes the prime responsibility of the state to provide the basic amenities to its citizens in an inclusive way. Irrespective of where they live, the citizens must be able to access clean water, education facility, health services, and opportunity for economic growth (Mac.Cllum et al., 2008; Sharma, 2014). It is therefore, under the new republican and federal Constitution of Nepal, the government has given priority to promote the urban growth system by increasing urban centers (Municipality) with adequate urban facilities (Birukou and Romarenko, 2016; MOUD, 2016). In Australian case, polycentric settlement network has considered as a means of double task for development activities as to improve the external role of cities that can the polycentric structure to a great extent and to avoid the dominance of monocentric structure of the settlement network (Briney, 2017). It could be more effective approach to ensure the social cohesion and economic competitiveness between center and neighbors in Nepalese case also.

It is important for the promotion of spatial planning at local level and spatial dimensions have to be taken into account to establish functional interdependencies and synergies in the line with local needs, energy policy and sustainable mobility. The development strategy has expected to promote the integrated and multisectral approaches for a balanced settlement cluster (polycentric centers) system and strengthening of the partnership between urban and rural areas which can overcome the outdated dualism between city and countryside (Nilsson, 2014).

In Nepal, Gurung (1969) first time introduced the growth pole and growth axis concept with a view to implement the regional development plan in a comprehensive way as a means of broadening the scope of the resource allocation at the local, regional and national levels by laying stress on the coordinative relations among development initiatives in geographic specific locations.

In above background, time has been presented on a key factor to promote the polycentric center settlement development to enhance the social and economic functions of the center to serve the population of the center and of its surroundings. This could also 
reduce the disparity between centers and surrounding neighbors in terms of human needs, satisfaction, infrastructure development and social services. The polycentric centers also supposed to increase the access to governance and government, increase in the transparency of public administrative services and empowerment of locals as the breeding grounds of social innovation and territorial development. In order to promote polycentric centers, it is necessary to identify the polycentric centers based on the role, functions and future development potentials of the existing settlements at the district level. Thus, this paper discusses the settlement structure in Baglung district, their hierarchy and a model how the identified polycentric centers can perform as the superior polycentric centers.

\section{Study Area}

Baglung district was selected for this study. This district was selected based on district level human development index(HDI) of the Province 4 in which Baglung district has low $\mathrm{HDI}(0.478)$ as compared to other districts in the province.(NPC, 2014). Topographically, Baglung is a hill district and this district also represents greater parts of Nepal which has same physical as well as socio-economic conditions. It has $1,784 \mathrm{~km}^{2}$ spatial coverage having 2,68,937 populations with 1,23,538 male and 1,45,409 female populations (CBS, 2012). In the political division, it has divided into two election constituent area, four municipalities and 6 rural municipalities (Figure 1).

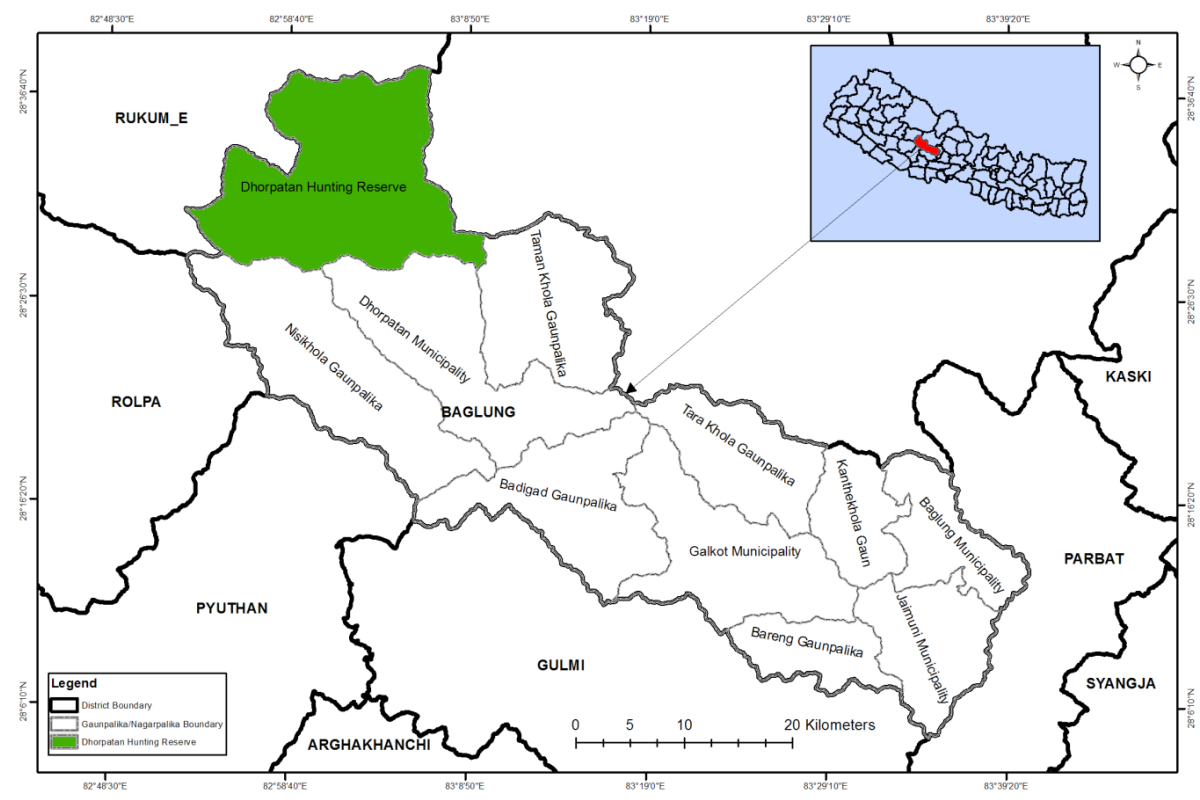

Figure-1: Location map of Baglung district 


\section{Methods and Approach}

The present study analyses the intensity of the relationships between the components of the settlements systems using multi-criteria evaluation approach which was used by Hossain, et.al (2007) for the GIS-based land-suitability classification in Bangladesh. This new and innovative approach to analyze the integrated settlement development is not only scientific, relevant and worldwide popular but also simple to frameout the polycentric settlement development in different spatial features and specificities of Nepal. Analyzing the equal importance by pared comparison of basic components of settlement center development; this approach gives a clear-cut picture of balanced and competitive settlement center development. This approach is also useful to identify the development issues, challenges and way out to solve through people-public-private partnership modality. Hence, this approach has been used to analyze the potentiality of polycentric development from the existing settlement system and their respective location. Six major aspects such as physical setting, infrastructure condition, level of social development, economy and livelihood opportunities, environmental condition and level of institutional development were considered as the major parameters. Using multi criteria decision making (MCDM) method from simple cross tabulation by using rank and weighted score of each parameters were converted ordinal scale in to ratio scale and even check its consistency.

Their respective value of each indicator was calculated by using analytic hierarchy process (AHP) which is popular as multi criteria decision making (MCDM) method. This was originally developed by Thomas L. Saaty in 1980 . This method used to derive ratio scales from paired comparisons which obtained from actual measurement weight from subjective opinion such as satisfaction, feelings and preferences. The ratio scales were derived from the principle of Eigen vectors and the consistency index which derived from the principle of Eigen value. The hierarchic order of the settlement locations was drawn from 1 level one comparison matrix corresponds to pair-wise comparisons between physical setting, physical infrastructure, social development, economy and livelihood opportunities, environmental conditions, and institutional development with respect to the goal of development. Thus, the comparison matrix of level 1 has been used in the size of 6 by 6 (Table 1 ). 
Table1: Polycentric center selection parameters and their comparative value

\begin{tabular}{|c|c|c|c|c|c|c|}
\hline Aspects & 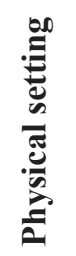 & 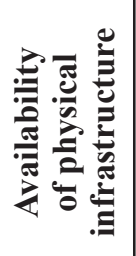 & 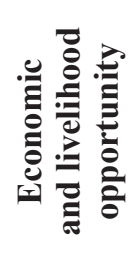 & 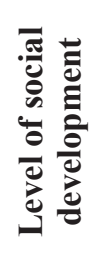 & 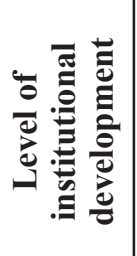 & 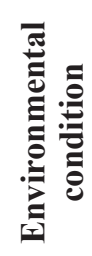 \\
\hline Physical setting & 1 & 3 & 2 & 2 & 3 & 2 \\
\hline Physical infrastructure & 0.33 & 1 & 0.5 & 2 & 2 & 3 \\
\hline Economic and livelihood opportunity & 0.5 & 2 & 1 & 2 & 2 & 2 \\
\hline Social development & 0.5 & 0.5 & 0.5 & 1 & 2 & 2 \\
\hline Institutional development & 0.33 & 0.5 & 0.5 & 0.5 & 1 & 0.5 \\
\hline Environmental aspects & 0.5 & 0.33 & 0.5 & 0.5 & 2 & 1 \\
\hline
\end{tabular}

Source: Hossain, 2007 \& personal computation

The reciprocal relationship between and among the parameters was determined by putting the actual judgment value and reciprocal value 6 by 6 in upper triangular matrix where the diagonal elements of the matrix are always 1 and need to fill up the upper triangular matrix. The actual judgment value put on the second row of the last column of the matrix. To fill the lower triangular matrix, used the reciprocal values of the upper diagonal as aij the element of row $i$ column $j$ of the matrix, then the lower diagonal was filled using following formula

$$
a i j=\frac{1}{a_{i j}}
$$

The priorities are determined by normalizing the pair-wise comparison matrix through diving each value of row by the total sum of all rows of the table. Averaging of row of such formed matrix denoted the prioritize weight (Table 2).

A consistency ratio was calculated for the pair-wise comparison matrix to verify the degree of credibility of the relative weights, by using the following ratio $C R=C I / R I$. Where $(\mathrm{RI})$ is the random consistency index for $\mathrm{n}$ (parameters) $=6, \mathrm{RI}=1.24$ (Alonso \& Lamata, 2006).

Required information like physical setting, geographical location, population size, economic activities and competitiveness, natural, cultural and financial resources capacity and the hinter land area of the selected settlement centers were collected using both primary and secondary sources of data. 
Table 2: Normalized weight matrix of indicators with their average value

\begin{tabular}{|c|c|c|c|c|c|c|c|}
\hline \multirow[b]{2}{*}{ Aspects } & \multicolumn{7}{|c|}{ Indicators } \\
\hline & 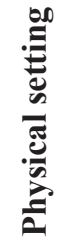 & 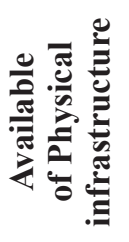 & 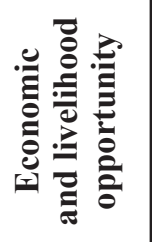 & 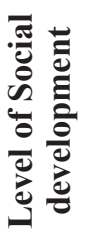 & 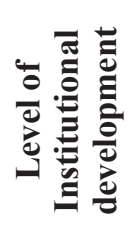 & 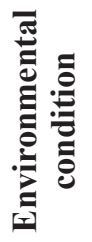 & 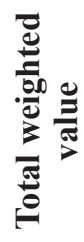 \\
\hline Physical setting & 0.32 & 0.41 & 0.40 & 0.25 & 0.25 & 0.19 & 30 \\
\hline Physical infrastructure & 0.11 & 0.14 & 0.10 & 0.25 & 0.17 & 0.29 & 17 \\
\hline $\begin{array}{l}\text { Economic and } \\
\text { livelihood opportunity }\end{array}$ & 0.16 & 0.27 & 0.20 & 0.25 & 0.17 & 0.19 & 21 \\
\hline Social development & 0.16 & 0.07 & 0.10 & 0.13 & 0.17 & 0.19 & 13 \\
\hline $\begin{array}{l}\text { Institutional } \\
\text { development }\end{array}$ & 0.11 & 0.07 & 0.10 & 0.06 & 0.08 & 0.05 & 8 \\
\hline Environmental aspects & 0.16 & 0.05 & 0.10 & 0.06 & 0.17 & 0.10 & 10 \\
\hline
\end{tabular}

Source: Saaty,(1980) \& Personal commutation

Number, types and physical forms of the settlement were identified based on the national guideline paper on compact settlement development (DUDBC/ CDG-TU, 2003) and Designation of hierarchy of humans settlements standards (DUDBC/ CDG-TU, 2004) using satellite image interpretation of the multi spectotral at which was taken in 2nd September, 2017 and toposheet at the scale of 1: 25000 which was prepared in1996 through aerial photo.

Information on level of physical infrastructure development and the level of social development, economic conditions, drinking water facility, electricity, information and communication, irrigation facility and transportation facilities were collected using secondary sources(CBS, 2012) and analyzed. Resources status and their analysis were made by applying participatory resource mapping (PRM) method during the field study period (27 September to October 13 $3^{\text {th }}, 2017$ ). More than 150 local people including FGD participants were actively involved to point out the spatial characteristics and intensity of available resources was taken into consideration as the PRM method during the field study period. Data regarding settlement functions, services area (hinterland) connectivity and settlement interrelationship, environmental conditions, livelihood opportunity, availability of land (public) and physical conditions and natural hazards and ecological sensitivity were collected through observation, Focus Group Discussion and Key Informant Interview. Twelve focus group discussions were conducted in 16 selected settlement centers by covering major geographical locations of the district. 
The participants of each group were 9-12 persons from the different areas that related to the polycentric settlement development. Similarly, Government officials and district level stakeholders were interviewed as the key informants of the study. The number of key informants was altogether 25 who were interviewed by using semi structure questionnaires. Settlements locations with score more than 30 were taken into consideration and followed the scheme used by Haris (2017) for ranking of potential polycentric centre. The then top ten rank order settlement centers were finalized through field verification. Then the average value of each indicators grouped into six parameters is mentioned in Table 1. Using matrix as shown in Table 2 of selected settlement locations were examined with suitability and capacity of the selected settlement location for promoting as the polycentric center according to their performance as nodes at the district and province level.

\section{Result and discussion}

This section discusses the number, types and physical forms of polycentric centre in general and settlement hierarchy to identify the potential polycentric settlement centers at district level.

\section{Types and forms of settlement}

It seems that the concentration of settlement is related to several factors like landform, soil types, and availability of natural resources, accessibility and social integration. These factors have varying degree of effects on types and forms of settlements in rural area of Nepal (Shrestha, 1980). Topographical features, climate, agricultural land, sources of food, fodder and fuel, and connectivity have significant role to determine the size, types and forms of rural settlement in Nepal. Using national concept paper on compact settlements 2003 and interpretation of satellite image the number, types and forms of settlements of the Baglung district have been presented in Table 3 .

Table 3:Types and forms of settlement of Baglung District

\begin{tabular}{|l|r|r|r|r|r|}
\hline \multirow{2}{*}{ Settlement types } & \multicolumn{3}{|c|}{ Settlement structure } & \multirow{2}{*}{ Total } & \multirow{2}{*}{ Percent } \\
\cline { 2 - 4 } & Block & Linear & Others & & \\
\hline Dispersed/scattered & & & 357 & 357 & $\mathbf{1 3 . 2 9}$ \\
\hline Agglomerate & 1068 & 1161 & & 2229 & $\mathbf{8 2 . 9 5}$ \\
\hline Compact & 83 & 18 & & 101 & $\mathbf{3 . 7 6}$ \\
\hline Total & 1151 & 1179 & 357 & 2687 & \\
\hline Percent & $\mathbf{4 2 . 8 4}$ & $\mathbf{4 3 . 8 8}$ & $\mathbf{1 3 . 2 9}$ & & \\
\hline
\end{tabular}

Source: Field study, 2017 \& satellite Image interpretation, 2017 
Table 3 shows that there is 2687 settlements in Baglung district. The proportion of agglomerate settlement found high (82.95\%) as compared to the compact settlement $(3.76 \%)$ as shown in Figure 2.In terms of the settlement structure, more than 42 percent settlements found in block structure and 43.88 percent in linear form.

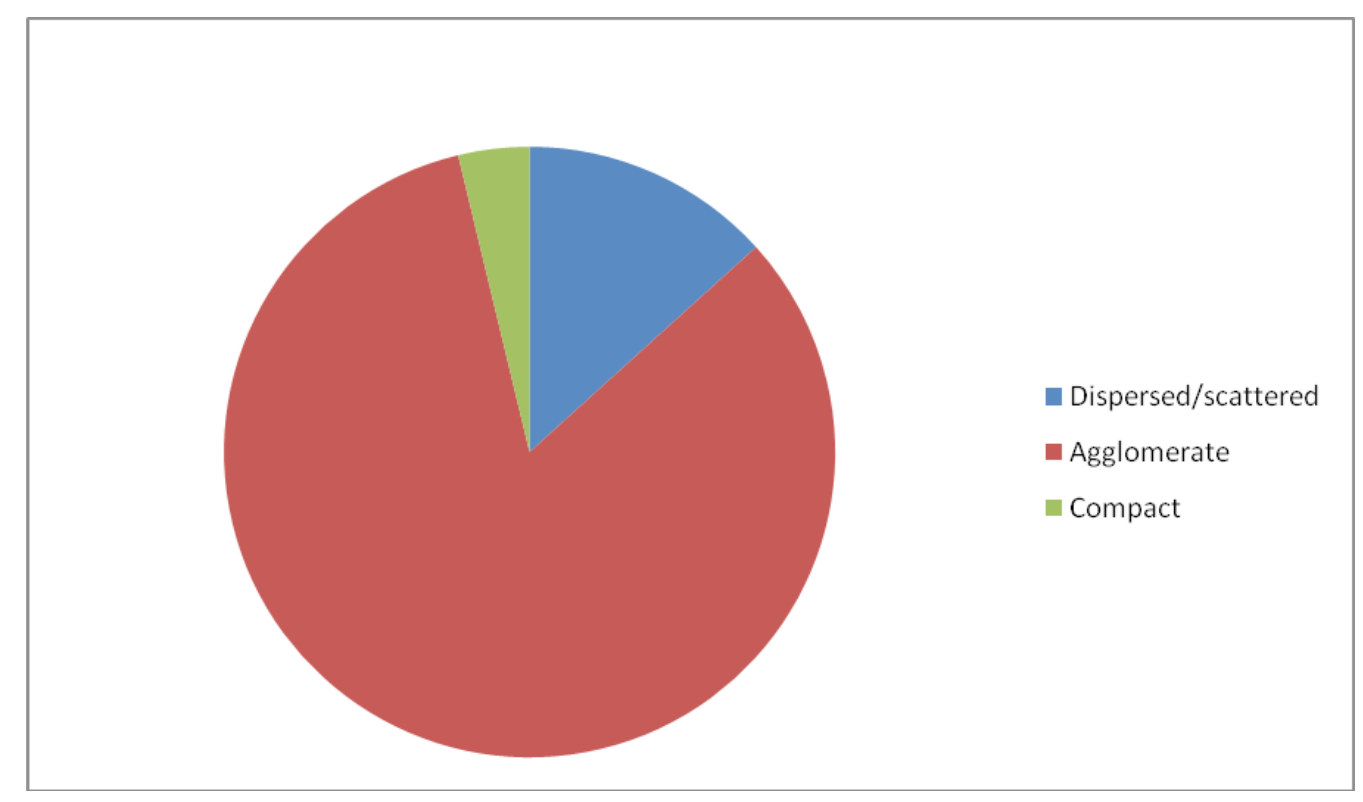

Figure 2: Settlement types in Baglung district

\section{Settlement hierarchy}

The position and rank are important for creating a hierarchy of space in dwellings and settlements. Thus, the spatial hierarchy of selected settlement locations was determined using multi criteria decision making methods and analytical hierarchy process. The average weighted value of each settlement was calculated from each indicator and the rank level prepared at the district level for promoting as polycentric settlement centers according their rank. The hierarchic order of the selected settlements of Baglung district has been presented in Table 4 . 
Table 4: Settlement hierarchy of selected settlements of Baglung District

\begin{tabular}{|c|c|c|c|c|c|c|c|c|}
\hline Rank & Name & 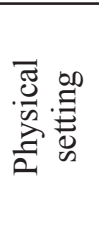 & 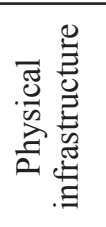 & 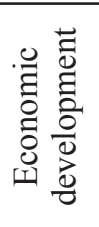 & 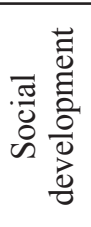 & 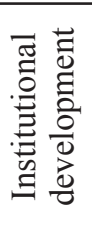 & 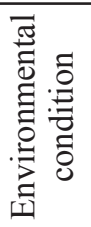 & 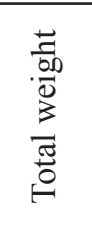 \\
\hline 1 & $\begin{array}{l}\text { Balewa, } \\
\text { (Narayansthan) }\end{array}$ & 24.53 & 13.11 & 13.18 & 8.76 & 6.1 & 6.09 & 71.77 \\
\hline 2 & KharaBajar & 20.95 & 15.72 & 17.78 & 3.44 & 3 & 6.55 & 67.44 \\
\hline 3 & MajuwaPhant & 19.34 & 15.35 & 16.83 & 6.03 & 4 & 5.5 & 67.05 \\
\hline 4 & Angkhet & 18.21 & 16.27 & 15.05 & 3.94 & 4 & 5.51 & 62.98 \\
\hline 5 & Nwara & 15.66 & 17 & 13.52 & 9.27 & 2.4 & 4.46 & 62.31 \\
\hline 6 & Harichaur & 17.41 & 11.54 & 15.35 & 5.56 & 6.1 & 5.37 & 61.33 \\
\hline 7 & $\begin{array}{l}\text { Pokhara Bihu, } \\
\text { (Lisepani\&Jukepani) }\end{array}$ & 12.22 & 14.8 & 14.4 & 7.24 & 4 & 6.03 & 58.69 \\
\hline 8 & Kushmisera & 15.82 & 11.48 & 13.94 & 7.42 & 5.2 & 3.03 & 56.89 \\
\hline 9 & $\begin{array}{l}\text { Nauthargaun, } \\
\text { Bobang, Thakali } \\
\text { Bhati, Masalgaun } \\
\text { (Serabang) }\end{array}$ & 20.15 & 6.44 & 13.76 & 7.32 & 1 & 6.55 & 55.22 \\
\hline 10 & Nisi & 20.95 & 9.27 & 10.18 & 5.73 & 2.9 & 2.51 & 51.54 \\
\hline 11 & $\begin{array}{l}\text { Lekhani, Kurlimare ( } \\
\text { Upallotar) }\end{array}$ & 11.56 & 10.75 & 11.86 & 8.99 & 4 & 4.28 & 51.44 \\
\hline 12 & NayanBajar & 15.66 & 9.15 & 11.98 & 4.42 & 2.9 & 5.37 & 49.48 \\
\hline 13 & Chhamri & 7.89 & 12.21 & 14.84 & 5.53 & 2.4 & 5.37 & 48.24 \\
\hline 14 & Taman & 12.78 & 8.31 & 12.82 & 4.19 & 2.4 & 3.03 & 43.53 \\
\hline 15 & Sormani & 9.96 & 9.71 & 10.48 & 2.55 & 1 & 4.28 & 37.98 \\
\hline 16 & Chautara ( Dipdanda) & 9.98 & 6.25 & 8.48 & 3.66 & 1.9 & 4.59 & 34.86 \\
\hline
\end{tabular}

Source: Calculated based on the data collected from secondary and primary sources

Table 4 evinces that out of the total number of settlement (2687) only 16 settlement locations were selected to develop as the polycentric settlement centers (Figure 3). After calculating the average value of the selected settlement, Balewa Narayansthan (71.77), top one rank settlement has been suggested to develop as the polycentric settlement in Baglung district in coming year. 


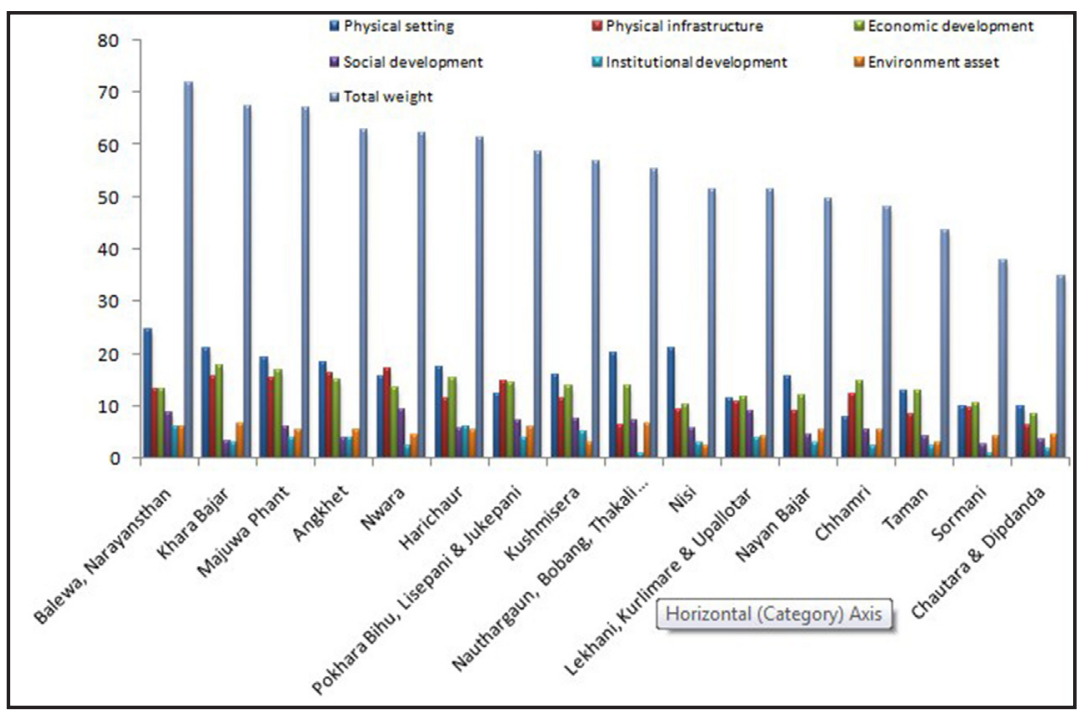

Figure 3: Settlement hierarchy of selected settlements of Baglung district

However, all the selected polycentric settlement centers (16) have to propose for the mission of polycentric settlement development in long term in Baglung district as a planning solution for achieving efficiency and sustainability goals in order to promote Polycentric-centered. Because these selected centers tend to be characterized by some degree of economic specialization, and can, therefore, referred to as development clusters. This result also corroborate by the studies of Talen, (2008); Moularet \& Nussbaumer, (2005a) and Anderson (2001) (Figure 4).

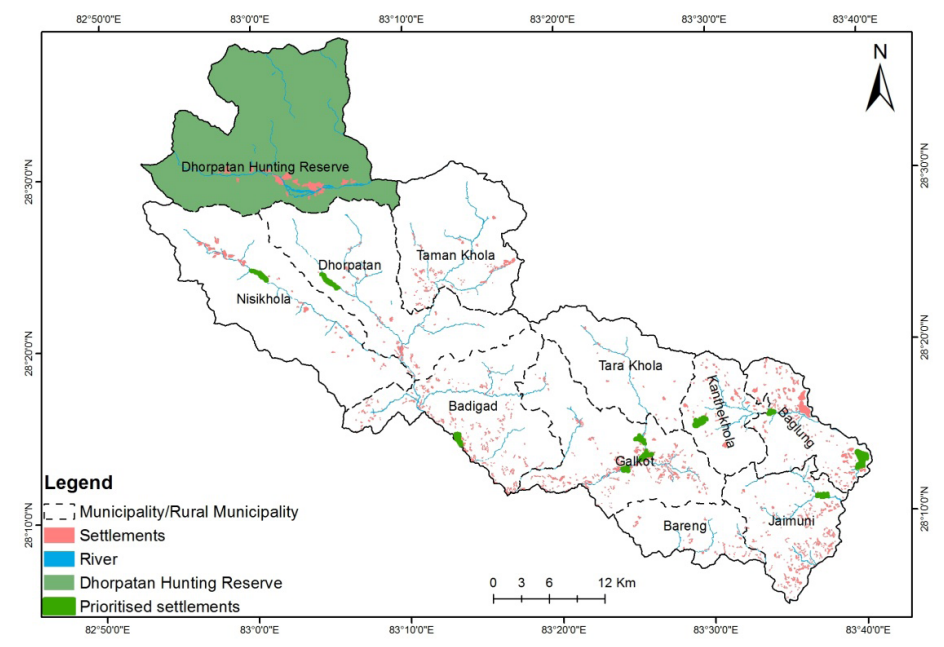

Figure 4: Potential polycentric settlement centers by local bodies in Baglung district 
At the time of field study most of the FGD participants emphasized the importance of harmonized actions to ensure the accomplishment of the common objectives within the limits of settlement centers' competences and social cohesion. Because the present existing pattern of urbanization and physical infrastructure development trends has not encouraged the potentiality of location-specific economic production, social innovation as to promote backward- forward linkage between service centers and neighbors. This shows that policy intervention is essential to provide joint, and harmonized responses to common problems. This means reconciling the social and economic claims for spatial development with the areas' ecological and cultural functions as contributing to a sustainable and balanced territorial development is a must in order to achieve economic competitiveness, environmental balance and social cohesion.

During the period of field study majority of the key informants viewed that specific and implementable national strategy for polycentric settlement development is essential to promote the location specific or spatial resource based economic activities, encourage to the small and medium entrepreneurship development, and to develop the indigenous skills and technology to sustain the economy and improve the livelihood by achieving the sustainable development goals at the settlement level. They further emphasized the effective population management, health, education and social security service delivery system and cost effective integrated infrastructure development activities need to prioritize in the national development strategy for ensuring the backward and forward linkage of neighbors and the centers. Moreover, key informants opined that spatial (territorial) identity, social innovations, cultural development and locationspecific productivity can be achieved by adopting polycentric development approach at the community level in the district. They equally focused the importance of such approach to consider environmental cost while physical infrastructure development are implemented for balanced, organized, sustainable, and have modern facilities at settlement level.. Therefore, sustainable use and conservation of available natural resource, promotion and preservation of cultural resources, ensuring the safety net of social and natural aspects are to be prioritized into the environmental conservation and development at the implementation level. It is therefore, the balanced and sustainable polycentric center development approach as a spatial development could be base for achieving targets of the Sustainable Development Goals (SDGs) as economic viable, social harmony and environmental balance at the district level by applying the proposed polycentric development model as shown in Figure 5. 


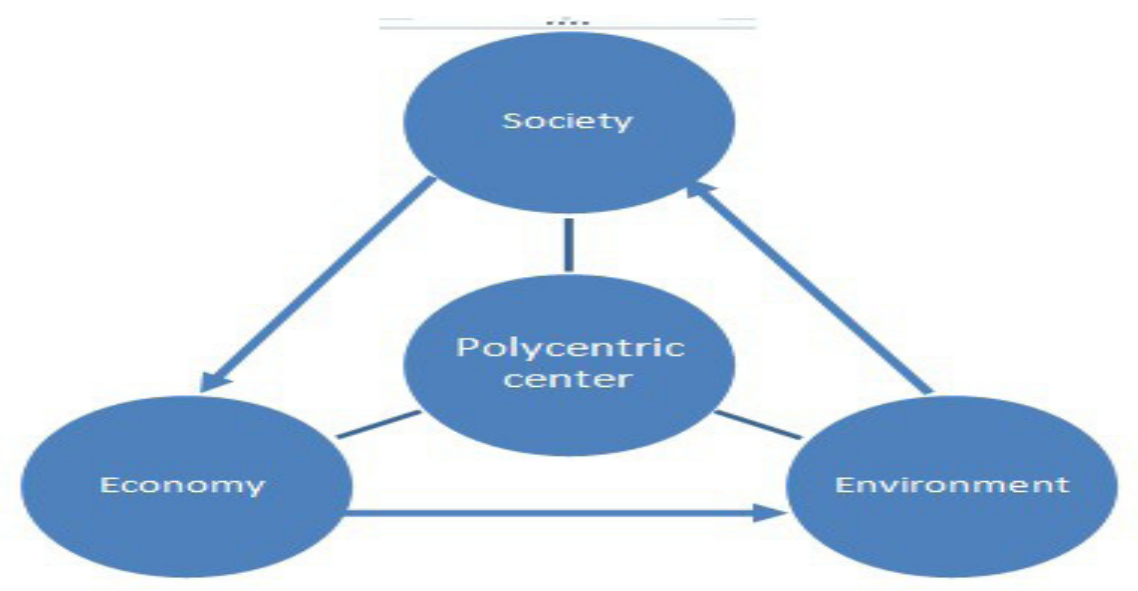

Figure 5: Balanced and sustainable polycentric development model

\section{Conclusion}

It can be concluded that the polycentric settlement center development activities at the district level is the essential task of the national government for the balanced and sustainablelivelihoodimprovement of rural communities. Polycentric center development efforts and initiations could play significant role to promote the culture of spatial development planning which further ensures the social, economic and environmental cohesion at the community level. It is therefore, polycentric development national strategies, policies and plans are prerequisites for achieving the goal of sustainable development and national prosperity as expected in the Constitution of Nepal. Because, polycentric centers not only promote agglomerative economies and facilitate economic growth, social integration; they also generate a disproportionate number of trips and promote accessibility network. Thus, the policy supports which need to promote such polycentric settlement (urban system) development at the local level is essential in order to improve the livelihood of the rural population and also meet the national goal of peace, prosperity, and sustainable progress is to be formulated and strictly implemented into practice. Hence, the proposed polycentric development model as a basis of achieving sustainable development could encourage neighborhood development within the shed of the centers and also contribute to strength on coordination of province and national level budgetary systems to balance development within a center's periphery. It is therefore, the development plan of the country has to encourage the concentration of economic and livelihood opportunities within polycentric settlement structure and to encourage spatial development by promoting territorial identity, social innovation and cultural development of the centers including their neighbors. 
Kabi Prasad Pokhrel; Gagan Ale andAshok Raut/The Geographical Journal of Nepal Vol. 11: 137-155, 2018

\section{References}

Alonso, J. A., \& Lamata, M. T. (2006). Consistency in the analytic hierarchy process: A new approach. International Journal of Uncertainty, Fuzziness and KnowledgeBased Systems, 14(04), 445-459, doi:10.1142/s0218488506004114

Anderson, N. B., \& Bogart, W. T. (2001). The structure of sprawl: Identifying and characterizing employment centers in polycentric metropolitan areas. American Journal of Economics and Sociology, 60(1): 147-169.

ADB, \& ICIMOD (2006). Environment assessment of Nepal Emerging issues and challenges. Kathmandu: Asian Development Bank \& International Centre for Integrated Mountain Development (ADB,\&ICIMOD).

Bevan, Andrew, \& Wilson, Alan (2013) Models for settlement hierarchy based on partial evidence. Journal of Archaeological Science

Biryukou, V. V., \& Romarenko, E.V. (2016). The formation of territorial innovation model. Indian journal of Science and Technology, 9(12): 1-10

Brandi, C. (2015). Goal 11 make cities and human settlements inclusive, safe, resilient and sustainable, in German development institute. the sustainable development goals of /to post 2015 Agade comments on the OWG and SDSN proposal

Briney, A. (2017). An overview of christaller's central place theory. Austrarlia: retripped Ltd/thought co.com

Brundtland, G. (1987). Our common future. Report of the 1987 World Commission on Environment and Development. New York: UNO.

CBS (2012). National population and housing census2011. Kathmandu: Central Bureau of Statistics (CBS).

Chou, T. L., Ching, C. H., Fan, S., \& Chang, J. Y. (2011). Global linkages, the Chinese high-tech community and industrial cluster development. Urban Studies, 48(14): 3019-3042.

Cruz, S. S., \& Teixeira, A. A. C. (2015). The neglected heterogeneity of spatial agglomeration and co-location patterns of creative employment: evidence from Portugal. Annals of Regional Science, 54:143-177.

DUDBC \& CDG/TU (2003). National concept paper on compact settlements 2061 (in Nepali) Kathmandu: Department of Urban Development and Building Construction and Central Department of Geography/ Tribhuvan University (DUDBC/ / CDG ,TU). 
Kabi Prasad Pokhrel; Gagan Ale andAshok Raut/ The Geographical Journal of Nepal Vol. 11: 137-155, 2018

DUDBC, \& CDG/TU. (2004). Designation of hierarchy of human settlements based on standards (in Nepali). Kathmandu: DUDBC and CDG /TU

DUDBC (2010). Settlement development directives 2067 B.S. with compact settlement development standards( in Nepali). Kathmandu: DUDBC/GoN

European Spatial Planning Observation Network (ESPON) (2014). Making Europe open and polycentric: Vision and scenarios for the European territory towards 2050. Luxembourg: European Union.

Eropean Spatial Development Perspectives (ESDP). (1999). European spatial development perspectives-1999 . (available at: htp//ec.europa.eu/regional policy sources/office/reports/pdf

Fujita, M., Krugman, P., \& Venables, A. J. (1999). The spatial economycities, regions and international trade. Cambridge MA: the MIT press.

Gurung, H.(1969). Regional development plan for Nepal. Kathmandu: National Planning Commission, HMG

Haris, M.P. (2017). Evaluating metropolitan spatial development a method for identifying settlement types and depicting growth patterns. Regional studies, Regional science vol: 7-25 (online journal)

Haindl, G., \& Hirschler, P. (2008). Metropolitan development and strategic positioning-planning efforts in selected cities on different levels. REAL CORP 008 Proceedings/Tagungsband,Vienna, May 19-21, 2008.

Hallgeir, A. (2004). Europa policéntrica: utopía o posibilidad? In: Romero, J. and Farinós, J. (eds), Ordenación del territorio y desarrollo territorial: el gobiernodelterritorio en Europa: tradiciones, contextos, culturasy nuevasvisiones, Gijón: Ediciones Trea, pp. 145-170.

Hall, P. (2009). Looking backward, looking forward: The city region of the Mid-21st century. Regional Studie, 43(6): 803-817.

Hossain, M. S., Chowdhury, S. R., Das, N. G., \& Rahaman, M. M. (2007). Multicriteria evaluation approach to GIS-based land-suitability classification for tilapia farming in Bangladesh. Aquaculture International, 15(6): 425-443. doi:10.1007/s10499-007-9109-y

Kavurmaci, M. (2016). Settlement suitability analysis using geographical information system (GIS): A case study in Aksaray, Turkey. J. Int. Environmental Application \& Science, 11(3): 229-240. 
Knaap, E., \& Ding, C. (2012). Polycentrism as a sustainable development strategy: Empirical analysis from the state of Maryland. Journal of Urbanism Planning: Practice and Prospect. Cambridge, MA: Lincoln Institute of Land Policy

Lynch. K. (1981). A theory of good city form .London: MIT press

MacCallum, D. J., Moulaert, F. J., Hillier, J., \& Vicari Haddock, S. (eds) (2008). Social innovation and territorial development. Union Road, England : Ashgate publishing Limited.

MOUD/GON (2016).Third United Nations Conference on housing and sustainable urban development (habitat iii), Nepal National report. Kathmandu: Ministry of Urban Development (MOUD/GON).

Moulaert, F., \& Nussbaumer, J. (2005a). The social region; beyond the territorial dynamics of the learning economy. European Urban and Regional Studies, 42:11: 2071-88.

MOUD/UDPPD (2017). National urban development strategy 2017.. Kathmandu: Ministry of Urban development/ Urban Development and Physical Planning Division (MOUD/UDPPD).

NFGM-VATI (2010). Local economic development: creative solutions, good practices. Budapest: National Ministry for Development Economy( available at: www.nfgm.gov.hu)

Niekerk, W. V. (2016). Revising the South African guidelines for human settlement planning and design. Available at https/www.Reseachgete.net /publication / 310800265

Nilsson, K. (2014). Strategies for sustainable urban development and urban rural linkages. European Journal of Spatial Development (online) www.nordregio. se/EJSD

Nishimura, J., \& Okamuro, H. (2011a). R\&D productivity and the organization of cluster policy: An empirical evaluation of the industrial cluster project in Japan. The Journal of Technology Transfer, 36(2): 117-144.

NPC (2013). Compact rural settlements development strategy for Nepal: A policy brief. Kathmandu: National Planning Commission (NPC).

NPC (2014). Nepal human development report 2014:Beyond geography, unlocking human potential. Kathmandu: National Planning Commission/ Government of Nepal. 
NPC (2015). Sustainable development goals, 2016-2030. Kathmandu: National Planning Commission/ Government of Nepal.

Peptenatu, D., Pintilii, R., Draghici, C., \& Peptenatu, A. (2012). The efficiency of polycentric development strategies in the context of economic crisis.Case study - the development of Southwest Oltenia region - Romania. In: Szymańska, D. and Biegańska, J. editors, Bulletin of Geography. Socio-economic Series, No. 17, Toruń: Nicolaus Copernicus University Press, pp. 117-125. DOI: http:// dx.doi.org/10.2478/v10089-012-0012-6

Saaty, T. L. (1980). The analytic hierarchy process. New York: Unknown.

Sharma, P. (2014). Urbanization and development. Population Monograph of Nepal 2014. Kathmandu: NPC/ CBS: 375-412.

Shrestha, C. B. (1980). The system of central places in the Arnokorajmarga area of Nepal, The Himalayan Review, Vol. VI: $n d$.

Talen, E. (2008). Beyond the front porch: Regionalist ideals in the new urbanist movement. Journal of Planning History, 7(1), 20-47. Retrieved from http:// www.sustainablecommunities.gov/aboutUs.html

Trullén, J., \& Boix, R. (2005).Knowledge, networks of cities and growth in regional urban systems, Working Paper 05.04. Departamentd Economia Aplicada, Universitat Autònoma de Barcelona. 